九州大学学術情報リポジトリ

Kyushu University Institutional Repository

Carcass Composition and Skeletal Muscle Distribution in Broilers Produced under Different Nutritional Regimes-3. Male Broilers Showing Maximum Early Growth and Restricted Later Growth

Das, Chamali

Graduate School of Bioresource and Bioenvironmental Sciences, Kyushu University

Roy, Bimol Chandra

Graduate School of Bioresource and Bioenvironmental Sciences, Kyushu University

Oshima, Ichiro

Graduate School of Bioresource and Bioenvironmental Sciences, Kyushu University

Miyachi, Hideyuki

Yokoo \& Co, Ltd

他

https://doi.org/10.5109/10070

出版情報：九州大学大学院農学研究院紀要. 53 (1)，pp.55-59，2008-02-28. Faculty of Agriculture， Kyushu University

バージョン :

権利関係 : 


\title{
Carcass Composition and Skeletal Muscle Distribution in Broilers Produced under Different Nutritional Regimes-3. Male Broilers Showing Maximum Early Growth and Restricted Later Growth
}

\author{
Chamali DAS ${ }^{1}$, Bimol Chandra ROY ${ }^{1 \S}$, Ichiro OSHIMA ${ }^{1 \S \S}$, Hideyuki MIYACHI ${ }^{2}$, \\ Shotaro NISHIMURA*, Shoji TABATA \\ and Hisao IWAMOTO
}

\author{
Laboratory of Functional Anatomy, Division of Animal science, Department of Animal and \\ Marine Bioresource Sciences, Faculty of Agriculture, Kyushu University, \\ Fukuoka 812-8581, Japan \\ (Received September 18, 2007 and accepted November 30, 2007)
}

1. In this study we investigated feeding methods which would lead to a high hind limb to wing muscle ratio in broilers. One group of male chicks was reared with a layer grower feed (LG, ME 11.92 MJ/kg, CP $170 \mathrm{~g} / \mathrm{kg}$ ) from 1 to 80 (LG80d) or 95 (LG95d) days of age. A further group of chicks was reared with a broiler starter feed (BS, ME $13.18 \mathrm{MJ} / \mathrm{kg}, \mathrm{CP} 205 \mathrm{~g} / \mathrm{kg}$ ) from 1 to 21 days and then with a pre-layer feed (PL, ME $11.72 \mathrm{MJ} / \mathrm{kg}$, CP $140 \mathrm{~g} / \mathrm{kg}$ ) up to 80 (BSPL80d) or 95 (BSPL95d) days.

2. LG80d (2490 g live weight) and BSPL80d (2648 g) birds did not attain sufficient body size ( $3 \mathrm{~kg}$ ) to slaughter at 80 days. LG95d (2979 g) and BSPL95d (3409 g) birds needed 15 extra days to attain a body size similar to conventionally-fed broilers. The rapid early growth induced by feeding the BS diet contributed greatly to increasing the ultimate body size of the broilers.

3. Carcass weight as a percentage of live weight was $83-85 \%$ in all broiler groups. Skeletal muscle as a whole accounted for $45-51 \%$ of carcass weight and the largest percentage was found in BSPL95d birds which were also the largest birds.

4. Wing muscle represented $21-23 \%$ of the total carcass weight. Hind limb muscle accounted for $18-21 \%$, and cervicodorsal muscle, $4.5-4.9 \%$ of total carcass weight. The hind limb weight as a percentage of wing muscle weight was similar among the chicken groups at 85-88\%, and this is larger than the value of 76\% found in previous work (Das et al., 2008b) and in conventionally-fed broilers (Roy et al., 2007).

5. From these results, it seems that the relative size of the hind limb to wing muscle is increased by restricting broiler growth during the pre-slaughter period and that early maximum growth has a positive effect on meat production by increasing carcass weight without altering the relative size of hind limb to wing muscle.

\section{INTRODUCTION}

The skeletal muscles that make up the breast meat of chicken, especially large muscles such as the pectoralis and supracoracoideus, are composed mainly of white (type IIB) myofibers while those in the thigh are made up of a range of myofiber types (type I, IIA and IIB) in the various individual muscles (Suzuki, 1978; Suzuki et al., 1985; Iwamoto et al., 1998; Roy et al., 2007). Rapid growth rate of muscle tissue arises from extensive development of existing myofibers (Mizuno and Hikami, 1971; Iwamoto et al., 1993; Ono et al., 1993); the white myofibers of the pectoralis muscle respond markedly to the nutritional level of the feed (Henkel, 1991; Tesseraud et al., 1996; Velotte and Crasto, 2004; Roy et al., 2006). In a general broiler, the

\footnotetext{
1 Laboratory of Functional Anatomy, Division of Animal Science, Department of Animal and Marine Bioresource Sciences, Graduate School of Bioresouce and Bioenvironmental sciences, Kyushu University, Fukuoka 812-8581, Japan

Yokoo \& Co, Ltd, Tosu-shi, 841-8602, Japan

\& Scientific Officer, Bangladesh Livestock Research Institute, Savar, Dhaka 1341, Bangladesh

$\$$ Assistant Professor, Department of Health and Nutrition, Niigata University of Health and Welfare 1398, Shimami-cho, Niigata-shi, 950-3198 Japan

* Corresponding author (E-mail: shotaro@agr.kyushu-u.ac.jp)
}

iliotibialis lateralis muscle in the thigh also contains a high proportion of white myofibers ensuring its rapid growth in birds on a high nutritional plane (Iwamoto et al., 1997, 1998).

Although limiting early growth rate results in relatively larger hind limb muscles in 3 week-old chicks, the muscle distribution of chicks' returns to normal in broilers after 3 weeks as a result of compensatory growth (Das et al., 2008a, b). In birds which show rapid growth rates in the later stage, the wing muscle recovers its superior size regardless of variation in its relative size in chicks at 3 weeks of age. It is possible that the relative size of the hind limb muscle of broilers could be increased relative to the size of wing muscle by limiting growth rate in chickens during the preslaughter phase.

In the present study, chicks were either fed a diet which limited growth throughout the experimental period or a diet which severely limited growth after the maximum growth phase in the first 3 weeks. Since neither group of broilers attained their target body weight ( $3 \mathrm{~kg}$ ) by 80 days, some of the birds were reared until 95 days of age. Body size, carcass composition and skeletal muscle distribution were compared between the treatment groups and with previous data (Das et al., 2008a, b). 


\section{MATERIALS AND METHODS}

\section{Experimental chicks}

One group of male chicks (Red Cornish $\times$ New Hampshire, Shaver, Fort Mèdoc, France) was subjected to a slow growth rate by feeding a layer grower complete feed (LG; metabolizable energy $11.92 \mathrm{MJ} / \mathrm{kg}$, crude protein $170 \mathrm{~g} / \mathrm{kg}$ ) (Marubeni Nisshin Feed Co. Ltd, Tokyo, Japan) throughout the experimental period up to 80 days (LG80d) or 95 days (LG95d). In a further group of the chicks, maximum growth during the first 3 weeks after hatching was ensured by feeding a broiler starter complete feed (BS; ME $13.18 \mathrm{MJ} / \mathrm{kg}, \mathrm{CP} 205 \mathrm{~g} /$ $\mathrm{kg}$ ) followed by a slower growth period which was achieved by feeding a pre-layer complete feed (PL; ME $11.72 \mathrm{MJ} / \mathrm{kg}, \mathrm{CP} 140 \mathrm{~g} / \mathrm{kg}$ ) until 80 (BSPL80d) or 95 days (BSPL95d). Throughout the experimental period, the cockerels were kept within a pen house and had ad-libitum access to experimental feeds and water.

Six of the LG80d, 8 of the LG95d, 8 of the BSPL80d and 7 of the BSPL95d cockerels were selected at random and killed by bleeding with a conventional neck cut following a $12 \mathrm{hr}$ overnight fast. Each carcass was then immersed in water at $60{ }^{\circ} \mathrm{C}$ for $120 \mathrm{sec}$. prior to plucking feathers and down. Each carcass was then chilled in an ice-water mixture for at least $1 \mathrm{hr}$ and weighed following decapitation at the atlanto-occipital joint and removal of the feet at the intertarsal joint. Carcass weight as a percentage of live weight was then calculated.

\section{Dissection of carcass}

Details of the dissection method for carcasses are given in a previous paper (Das et al., 2008a). Total weight of skin, visceral organs and abdominal fat were measured. Wing, hind limb and cervicodorsal parts were dissected into skeletal muscle, intermuscular fat and bone tissues and the weight of each part was measured from the combined weight of these tissue components.

Skeletal muscle weight was measured in 4 subparts of the wing, 3 subparts of the hind limb and 2 subparts of the cervicodorsal portion on the left side of the carcass (Vollmehrhaus, 1992). The 4 subparts of wing muscle were shoulder girdle, brachial, antebrachial and abdominal muscles. The hind limb muscle was composed of pelvic, femoral and crural subparts and the cervicodorsal muscle was divided into the dorsocaudal and cervical muscle subparts.

The weights of the pectoralis, supracoracoideus, triceps brachii, biceps brachii, iliotrochanterici, iliotibialis cranialis, iliotibialis lateralis, femorotibiales, flexor cruris lateralis, puboischiofemoralis and gastrocnemius muscles were measured on the right side of the carcass.

\section{Statistical analysis}

In this study, all the parameters were expressed as relative weight (\%) of carcass. Differences in parameters among experimental groups were assessed for statistical significance using one-way analysis of variance (Steel and Torrie, 1980) and the 95\% probability threshold was taken as indicating statistical significance.

\section{RESULTS}

\section{Live weight and carcass weight}

The feeding systems used in this study did not lead to sufficient body size of broilers by 80 days of age and a further 15 days of growth were required to attain slaughter weight (Table 1). The highest live weight was observed in BSPL95d cockerels, followed by LG95d birds, BSPL80d birds, and finally LG80d birds. Carcass weight as a percentage of live weight was $83-85 \%$ in all chicken groups.

Table 1. Comparison of live weight, carcass weight and percentage, and percentages of total muscle, bone, intermuscular fatty tissue, viscera, skin and abdominal fat on carcass weight among the broilers

\begin{tabular}{lllll}
\hline Broiler groups & LG80d & LG95d & BSPL80d & BSPL95d \\
\hline No of birds & 6 & 8 & 8 & 7 \\
Live weight (g) & $2490 \pm 155 \mathrm{c}$ & $2979 \pm 67 \mathrm{~b}$ & $2648 \pm 98 \mathrm{c}$ & $3409 \pm 116 \mathrm{a}$ \\
Carcass weight (g) & $2098 \pm 124 \mathrm{c}$ & $2479 \pm 55 \mathrm{~b}$ & $2241 \pm 84 \mathrm{c}$ & $2871 \pm 103 \mathrm{a}$ \\
Percentage of carcass & 84.3 & 83.2 & 84.6 & 84.2 \\
Carcass composition (\%) & & & & \\
$\quad$ Total muscle & $45.0 \pm 0.9 \mathrm{~b}$ & $49.0 \pm 0.6 \mathrm{a}$ & $46.7 \pm 0.6 \mathrm{~b}$ & $50.5 \pm 1.3 \mathrm{a}$ \\
$\quad$ Total bone & $15.2 \pm 0.5 \mathrm{a}$ & $14.6 \pm 0.3 \mathrm{a}$ & $16.1 \pm 0.5 \mathrm{a}$ & $15.2 \pm 0.6 \mathrm{a}$ \\
$\quad$ Total intermuscular fat & $3.11 \pm 0.28 \mathrm{a}$ & $2.69 \pm 0.12 \mathrm{a}$ & $3.01 \pm 0.24 \mathrm{a}$ & $3.39 \pm 0.40 \mathrm{a}$ \\
$\quad$ Visceral & $20.1 \pm 0.4 \mathrm{a}$ & $17.5 \pm 0.6 \mathrm{~b}$ & $18.4 \pm 0.5 \mathrm{ab}$ & $14.94 \pm 0.34 \mathrm{c}$ \\
$\quad$ Skin & $11.9 \pm 0.4 \mathrm{a}$ & $11.7 \pm 0.3 \mathrm{a}$ & $11.3 \pm 0.6 \mathrm{a}$ & $11.3 \pm 0.6 \mathrm{a}$ \\
$\quad$ Abdominal fat & $3.27 \pm 0.52 \mathrm{a}$ & $3.02 \pm 0.22 \mathrm{a}$ & $2.95 \pm 0.40 \mathrm{a}$ & $3.04 \pm 0.45 \mathrm{a}$ \\
\hline
\end{tabular}

Means \pm standard errors

LG80d and LG95d; Broilers fed Layer grower diet by 80 or 95 days.

BSPL80d and BSPL95d; Broilers fed Broiler starter diet by 21 days and then Pre-layer diet up to 80 or 95 days.

a, b, c; Means with the same letter did not differ significantly between chick's groups at $5 \%$ level. 


\section{Carcass composition}

Skeletal muscle as a whole accounted for a higher percentage (49-51\%) of the carcass in BSPL95d and LG95d broilers with their larger body size than in LG80d and BSPL80d birds (45-47\%; Table 1). The weight of the viscera as a percentage of carcass weight was highest (20\%) in LG80d birds; these birds also had the smallest body size of all the broiler groups. The relative weight of the viscera was $18-14 \%$ in the other broilers and differed significantly among groups except LG95 and BSPL80 birds. The total weight of bone as a percentage of carcass weight was higher in BSPL80d than in LG95d birds. Skin represented $11-12 \%$ of carcass weight in all broiler groups; intermuscular and abdominal fats accounted for $2.7-3.4 \%$ and $2.7-3.3 \%$ of carcass weight respectively.

\section{Skeletal muscle weight in parts and subparts}

The relative size of hind limb to wing muscle was
85.4-87.6\% in all broiler groups (Table 2) and this was greater than the values of $75.9-76.5 \%$ recorded in a previous study for chickens grown rapidly following a period of severe growth limitation during early growth (Das et al., 2008b) and the value of $76.5 \%$ recorded in normal feeding broilers (Roy et al., 2007). The wing muscle accounted for a larger percentage of carcass weight in the larger-bodied broilers and differed significantly only between the large BSPL95d birds and the small LG80d birds. The hind limb muscle also accounted for a higher percentage of carcass weight in larger broilers (BSPL95d). The cervicodorsal muscle accounted for a larger percentage of carcass weight in LG95d compared with LG80d birds.

The wing muscle consisted of one large shoulder girdle subpart and three small subparts with the large one representing $76-78 \%$ of the total weight. In the hind limb muscle, the femoral subpart was a little larger than the crural subpart, and the former accounted for

Table 2. Comparison of percentage weights of muscle groups and subgroups to carcass weight among the broiler groups

\begin{tabular}{lllll}
\hline Broiler groups & \multicolumn{1}{c}{ LG80d } & \multicolumn{1}{c}{ LG95d } & \multicolumn{1}{c}{ BSPL80d } & BSPL95d \\
\hline Wing muscles & & & & \\
$\quad$ Shoulder girdle m. & $15.99 \pm 0.28 \mathrm{~b}$ & $17.43 \pm 0.34 \mathrm{ab}$ & $16.83 \pm 0.41 \mathrm{ab}$ & $18.43 \pm 0.66 \mathrm{a}$ \\
$\quad$ Brachial m. & $2.09 \pm 0.05 \mathrm{a}$ & $2.23 \pm 0.07 \mathrm{a}$ & $2.19 \pm 0.04 \mathrm{a}$ & $2.12 \pm 0.06 \mathrm{a}$ \\
Antebrachial m. & $1.89 \pm 0.03 \mathrm{a}$ & $1.95 \pm 0.07 \mathrm{a}$ & $1.91 \pm 0.04 \mathrm{a}$ & $1.91 \pm 0.09 \mathrm{a}$ \\
$\quad$ Abdominal m. & $0.97 \pm 0.01 \mathrm{a}$ & $1.00 \pm 0.03 \mathrm{a}$ & $1.03 \pm 0.03 \mathrm{a}$ & $1.02 \pm 0.04 \mathrm{a}$ \\
$\quad$ Combined & $20.94 \pm 0.44 \mathrm{~b}$ & $22.61 \pm 0.35 \mathrm{ab}$ & $21.96 \pm 0.38 \mathrm{ab}$ & $23.48 \pm 0.88 \mathrm{a}$ \\
Hindlimb muscles & & & & \\
$\quad$ Pelvic m. & $1.57 \pm 0.12 \mathrm{a}$ & $1.72 \pm 0.06 \mathrm{a}$ & $1.74 \pm 0.09 \mathrm{a}$ & $1.79 \pm 0.09 \mathrm{a}$ \\
$\quad$ Femoral m. & $9.01 \pm 0.24 \mathrm{~b}$ & $9.44 \pm 0.23 \mathrm{ab}$ & $9.07 \pm 0.15 \mathrm{~b}$ & $10.08 \pm 0.24 \mathrm{a}$ \\
$\quad$ Crural m. & $7.69 \pm 0.18 \mathrm{~b}$ & $8.49 \pm 0.18 \mathrm{ab}$ & $7.94 \pm 0.11 \mathrm{ab}$ & $8.71 \pm 0.28 \mathrm{a}$ \\
$\quad$ Combained & $18.27 \pm 0.35 \mathrm{c}$ & $19.65 \pm 0.33 \mathrm{ab}$ & $18.75 \pm 0.27 \mathrm{bc}$ & $20.58 \pm 0.46 \mathrm{a}$ \\
Cervicodorsal muscles & & & & \\
$\quad$ Dorsocaudal m. & $1.71 \pm 0.05 \mathrm{~b}$ & $2.10 \pm 0.05 \mathrm{a}$ & $1.88 \pm 0.04 \mathrm{ab}$ & $1.98 \pm 0.05 \mathrm{a}$ \\
$\quad$ Cervical m. & $2.75 \pm 0.09 \mathrm{a}$ & $2.81 \pm 0.10 \mathrm{a}$ & $2.89 \pm 0.08 \mathrm{a}$ & $2.75 \pm 0.11 \mathrm{a}$ \\
$\quad$ Combained & $4.46 \pm 0.17 \mathrm{~b}$ & $4.91 \pm 0.14 \mathrm{a}$ & $4.77 \pm 0.16 \mathrm{ab}$ & $4.73 \pm 0.06 \mathrm{ab}$ \\
$\%$ of hindlimb to wing muscles & $87.2 \pm 1.2 \mathrm{a}$ & $86.9 \pm 1.7 \mathrm{a}$ & $85.4 \pm 1.4 \mathrm{a}$ & $87.6 \pm 2.2 \mathrm{a}$ \\
\hline
\end{tabular}

Means \pm standard errors

BF; Broiler finisher fed birds, LS; Layer starter fed birds, LG; Layer grower fed birds, and PL; Pre-layer fed birds.

a, b, c; Means with the same letter did not differ significantly between chick's groups at $5 \%$ level.

Table 3. Percentage weights of individual muscle to carcass weights in the broilers

\begin{tabular}{lllll}
\hline Broiler groups & LG80d & LG95d & BSPL80d & BSPL95d \\
\hline M. pectoralis & $9.82 \pm 0.25 \mathrm{~b}$ & $10.78 \pm 0.24 \mathrm{ab}$ & $10.43 \pm 0.41 \mathrm{ab}$ & $11.91 \pm 0.44 \mathrm{a}$ \\
M. supracoracoideus & $3.27 \pm 0.06 \mathrm{~b}$ & $3.59 \pm 0.08 \mathrm{ab}$ & $3.31 \pm 0.08 \mathrm{~b}$ & $3.87 \pm 0.15 \mathrm{a}$ \\
M. triceps brachii & $0.90 \pm 0.05 \mathrm{a}$ & $0.96 \pm 0.03 \mathrm{a}$ & $0.90 \pm 0.03 \mathrm{a}$ & $0.95 \pm 0.03 \mathrm{a}$ \\
M. biceps brachii & $0.48 \pm 0.03 \mathrm{a}$ & $0.49 \pm 0.02 \mathrm{a}$ & $0.51 \pm 0.01 \mathrm{a}$ & $0.52 \pm 0.02 \mathrm{a}$ \\
Mm. iliotrochanterici & $1.25 \pm 0.09 \mathrm{a}$ & $1.38 \pm 0.05 \mathrm{a}$ & $1.23 \pm 0.07 \mathrm{a}$ & $1.42 \pm 0.03 \mathrm{a}$ \\
M. iliotibialis cranialis & $0.72 \pm 0.03 \mathrm{a}$ & $0.76 \pm 0.03 \mathrm{a}$ & $0.75 \pm 0.02 \mathrm{a}$ & $0.82 \pm 0.04 \mathrm{a}$ \\
M. iliotibialis lateralis & $1.93 \pm 0.12 \mathrm{ab}$ & $1.91 \pm 0.06 \mathrm{~b}$ & $1.83 \pm 0.02 \mathrm{~b}$ & $2.16 \pm 0.05 \mathrm{a}$ \\
Mm. femorotibiales & $2.34 \pm 0.10 \mathrm{~b}$ & $2.76 \pm 0.04 \mathrm{a}$ & $2.45 \pm 0.04 \mathrm{ab}$ & $2.51 \pm 0.09 \mathrm{ab}$ \\
M. flexor cruris lateralis & $0.99 \pm 0.07 \mathrm{~b}$ & $1.07 \pm 0.06 \mathrm{ab}$ & $1.01 \pm 0.03 \mathrm{~b}$ & $1.30 \pm 0.10 \mathrm{a}$ \\
M. puboischiofemoralis & $0.94 \pm 0.03 \mathrm{~b}$ & $1.06 \pm 0.02 \mathrm{a}$ & $0.96 \pm 0.02 \mathrm{ab}$ & $1.03 \pm 0.02 \mathrm{ab}$ \\
M. gastrocnemius & $2.82 \pm 0.11 \mathrm{c}$ & $3.35 \pm 0.07 \mathrm{~b}$ & $3.13 \pm 0.07 \mathrm{~b}$ & $3.53 \pm 0.06 \mathrm{a}$
\end{tabular}

Means \pm standard errors

BF; Broiler finisher fed birds, LS; Layer starter fed birds, LG; Layer grower fed birds, and PL; Pre-layer fed birds.

a, b, c; Means with the same letter did not differ significantly between chick's groups at $5 \%$ level. 
$48-49 \%$ of the hind limb muscle while the latter accounted for $42-43 \%$. The cervicodorsal muscle was composed of a larger cervical subpart and a smaller dorsocaudal subpart.

\section{Individual skeletal muscles}

A notably large pectoralis muscle accounted for the largest percentage of carcass weight in the largest BSPL95d birds, followed by the LG95d and the BSPL80d broilers; the smallest percentage of carcass weight was found in the LG80d broilers which were also the smallest birds (Table 3). Changes in the size of the supracoracoideus and gastrocnemius muscles relative to carcass weight changed after the same manner as the pectoralis muscle among all the broiler groups. The iliotibialis lateralis and flexor cruris lateralis muscles were largest in BSPL95d birds and the femorotibiales and puboischiofemoralis muscles were largest in LG95d birds. The size of the other small muscles relative to carcass weight did not differ among the different group of broilers.

\section{DISCUSSION}

Live weight was greater in BSPL80d than in LG80d broilers. Live weight was also greater in BSPL95d than in LG95d birds demonstrating that the larger body size induced by feeding a high nutrition feed (broiler starter) similar to broiler finisher diet for 3 weeks posthatching (Das et al., 2008a) was maintained through to slaughter. On the other hand, chicks on a restricted plane of nutrition during the first 3 weeks showed compensatory growth after 3 weeks on a broiler finisher feed with a high nutritional content (Das et al., 2008b). Nutritionally-rich diets such as broiler feeds can accelerate growth whenever they are fed regardless of the growth stage and they play an important role in determining the ultimate body size of broilers. Carcass weight as a percentage of live weight was $84 \%$ and did not differ among the broiler groups in this or previous studies regardless of body size (Das et al., 2008b). However, skeletal muscle as a whole accounted for a higher percentage of heavier carcasses. As skeletal muscle shows a positive allometric relationship with body weight (Iwamoto et al., 1977, 1993; Ono et al., 1989), the change in carcass weight from 2098 to $2871 \mathrm{~g}$ across the broiler groups led muscle weight as a percentage of carcass weight to increase from $45.0 \%$ to $50.5 \%$. In a recent trial, broilers reared with a conventional broiler feed reached a carcass weight of $2970 \mathrm{~g}$ by 80 days of age and skeletal muscle accounted for $49.2 \%$ of carcass weight (Roy et al., 2007).

In the current study, hind limb weight relative to wing muscle weight was $75.9-76.5 \%$ in broilers fed on a high nutritional plane in the later growth stages after severe restriction of early growth compared to a value of $76.5 \%$ in broilers fed conventionally and killed at 80 days (Roy et al., 2007; Das et al., 2008b). Moreover, in broilers at 80 days of age which were reared with a layer starter feed for the first 3 weeks and then a layer grow- er feed, hind limb weight relative to wing muscle weight was 82.2\% (Roy et al., 2007). In LG80d and BSPL80d broilers, the relative weight of hind limb muscle to wing muscle weight was $85.4-87.2 \%$ which is distinctly larger than the value of $76.5 \%$ measured in conventionallyfed broilers. While in normal broilers the wing and hind limb muscles account for $25.2 \%$ and $19.4 \%$ of carcass weight respectively, in LG80d and BSPL80d birds, values for wing muscle were $20.9-22.0 \%$ and for hind limb muscle, $18.3-18.8 \%$. In particular, the shoulder girdle muscle of the wing in the LG80d and BSPL80d birds made up 16.0-16.8\% of carcass weight and this value was lower than the $20.3 \%$ value measured in conventionally-fed broilers (Roy et al., 2007). The larger relative size of the hind limb muscle in both types of broilers in the present study may have been produced by slow growth of the wing muscle rather than accelerated development of the hind limb muscle. The wing muscle seemed to be more responsive to variation in body growth induced by feeding diets with different nutrient concentrations compared with the hind limb muscle. However, the relative size of hind limb to wing muscle in LG95d and BSPL95d birds was maintained at a high level (86.9-87.6\%) while the percentage of total muscle weight to carcass weight increased to 49.0 $50.5 \%$. From these results, it appears that chickens showing slow growth in the pre-slaughter stage produce relatively larger hind limb muscles. Details of how the duration and extent of growth restriction before slaughter influence hind limb muscle weight of broilers remain to be elucidated.

The yield of breast meat from chickens gradually increases in the post-hatching growth stages up to 85 days of age (Havenstein et al., 2003). Major muscles of the breast (shoulder girdle) such as the pectoralis and supracoracoideus are typical white muscle composed of white myofibers (Suzuki, 1978; Ono et al., 1993; Iwamoto et al., 1998) which are characterized by an effective response to nutritional condition in chickens (Tesseraud et al., 1996). Variation in pectoralis volume is caused solely by changes in the cross sectional area or diameter of white myofibers (Roy et al., 2006). Japanese native crossbred broilers or roasters grow slowly but produce a darker meat in the thigh where the iliotibialis lateralis muscle contains red (type IIA) myofibers at higher frequency than found in general broilers (Iwamoto et al., 1997; 1998). Since white myofibers in thigh muscles respond effectively to the nutritional plane of chickens in the same way as for breast muscles, crossbred broilers would appear to be suitable for production of chickens with relatively larger hind limb parts compared to general broilers.

In conclusion, the observed relatively larger hind limb to wing muscle ratio appears to have resulted from growth limitation in the later stages of growth after 3 weeks of age. Variation in growth rate during the first 3 weeks post-hatching altered ultimate body weight of broilers but did not alter the relative size of hind limb muscle. From these results, it appears that broilers such as Japanese native crossbred birds produce more 
dark meat by increasing the relative size of hind limb muscle under a slow growth regime during the preslaughter period.

\section{REFERENCES}

DAS, C., ROY, B. C., OSHIMA, I., MIYACHI, H., NISHIMURA, S., TABATA, S. \& IWAMOTO, H. 2008a Carcass composition and skeletal muscle distribution in broilers produced under different nutritional regimes-1. Male chicks at three weeks of age. Journal of Faculty of Agriculture, Kyushu University, 53: 43-47

DAS, C., ROY, B. C., OSHIMA, I., MIYACHI, H., NISHIMURA, S., TABATA, S. \& IWAMOTO, H. 2008b Carcass composition and skeletal muscle distribution in broilers produced under different nutrition regimes-2. Male broilers fed for rapid later growth following severe nutritional restriction during early growth. Journal of Faculty of Agriculture, Kyushu University, 53: 49-53

HAVENSTEIN, G. B., FERKET, P. R. \& QURESHI, M. A. 2003 Carcass composition and yield of 1957 versus 2001 broiler diets. Poultry Science, 82: 1509-1518

HENKEL, P. 1991 Can meat quality be assessed hitochemically? Developmental Animal Veterinary Science, 25: 212

IWAMOTO, H., TAKAHARA, H. \& OKAMOTO, M. 1977 Effects of breed and sex on the total weight of skeletal muscle in the chicken. Japanese Journal of Zootechnical Science, $\mathbf{4 8}$ : 308-314

IWAMOTO, H., HARA, Y., GOTOH, T., ONO, Y. \& TAKAHARA, H. 1993 Different growth rates of male chicken skeletal muscles related to their histochemical properties. British Poultry Science, 34: 925-938

IWAMOTO, H., FUKUMITSU, Y., MATSUZAKI, M., TAKEMOTO, Y., MORITA, S. \& TAKAHARA, H. 1997 Comparative studies on the histochemical properties of M. iliotibialis lateralis from Kumamoto Cochin crossbred roaster and broiler chickens. British Poultry Science, 38: 258-262

IWAMOTO, H., KATOH, F., GOTOH, T., NISHIMURA, S., ONO, Y., NISHIO, Y., FUKUHARA, E. \& MURAKAMI, T. 1998 Effects of parent Shamo cocks on the histochemical properties of M. iliotibialis lateralis and M. supracoracoideus on their crossbred broilers. British Poultry Science, 39: 589_
595

MIZUNO, T. \& HIKAMI, Y. 1971 Comparison of muscle growth between meat-type and egg-type chickens. Japanese Journal of Zootechnical Science, 42: 526-532

ONO, Y., IWAMOTO, H. \& TAKAHARA, H. 1989 Allometry of body weight, skeletal muscle weight and muscle fiber diameter in the chick. Japanese Journal of Zootechnical Science, 60: 958-964

ONO, Y., IWAMOTO, H. \& TAKAHARA, H. 1993 The relationship between muscle growth and the growth of different fiber types in the chicken. Poultry Science, 72:568-576

ROY, B. C., OSHIMA, I., MIYACHI, H., SHIBA, N., NISHIMURA, S., TABATA, S. \& IWAMOTO, H. 2006 Effects of nutritional level on muscle development, histochemical properties of myofibre and collagen architecture in the pectoralis muscle of male broilers. British Poultry Science, 47: 433-442

ROY, B. C., OSHIMA, I., MIYACHI, H., NISHIMURA, S., TABATA, S. \& IWAMOTO, H. 2007 Effects of nutritional level and carcase weight on the different anatomical body parts and muscle weights of male broilers. Journal of Faculty of Agriculture, Kyushu University, 52: 43-48

STEEL, R. G. D. \& TORRIE, J. H. 1980 Principles and procedures of statistics: A biometrical approach (2nd Ed.). McGraw-Hill Inc., New York, USA

SUZUKI, A. 1978 Histochemistry of the chicken muscles II. Distribution and diameter of 3 fiber types. Tohoku Journal of Agricultural Research, 29: 38-43

SUZUKI, A., TSUCHIYA, T., OHWADA, S. \& TAMATE, H. 1985 Distribution of myofiber types in thigh muscles of chickens. Journal of Morphology, 185: 145-154

TESSERAUD, S., MAAA, N., PERESSON, R. \& CHAGNEAU, A. M. 1996 Relative responses of protein turnover in three different muscles to dietary lysine deficiency in chicks. British Poultry Science, 37: 641-650

VELOTIE, S. \& CRASTO, A. 2004 Histochemical and morphometrical characterization and distribution of fiber types in four muscles of ostrich (Struthio camelus). Anatomica Histologia Embyologia, 33: 251-256

VOLLMEHRHAUS, B. 1992 Anatomie des Bewengungsaparates. Lehrbuch der Anatomie der Haustiere, Band V. A Schmmer \& B. Vollmehrhaus, ed. Paul Parey, Berlin, Germany. pp. 54-154 